\title{
Research-driven Practice teaching Reform of Automation Professional of Engineering Colleges
}

\author{
Yihua Liu ${ }^{1, a}$, Guangzhou Zhao ${ }^{2, b}$ \\ ${ }^{1}$ Ningbo Institute of technology, Zhejiang University, Ningbo, 315100, China \\ ${ }^{2}$ College of Electrical Engineering, Zhejiang University, Hangzhou, 310027, China \\ a email: lyh@nit.zju.edu.cn, bemail: zhaogz@cee.zju.edu.cn
}

\section{Keywords: Research-driven; Automation Professionals; Practice teaching Reform}

\begin{abstract}
As an important part of the process of application-oriented personnel training, practical teaching plays a special role in cultivating students' practical ability and innovative spiritual training, while theoretical teaching cannot. Based on many years of practice teaching mode reform, the research-driven practical teaching mode is summed up and addressed separately from the reform objectives, reform thinking, reform contents and related policies. The measures and experiences can also be extended to other engineering specialties.
\end{abstract}

\section{Introduction}

With the continuous development of modern educational science, the educational contents and teaching methods had been constantly updated. The practical teaching has become an important part of education to implement the quality education and train of the scientific literacy and practical innovation ability of the college students. In the "National Long-term Education Reform and Development Plan (2010-2020)" issued by Ministry of Education, it called for the innovative training model, especially in the field of higher education, to strengthen practical teaching and pay attention to the training of learning ability, practical ability and creative ability of the college students. And in the Undergraduate Teaching Assessment of the Ministry of Education, practice teaching has also been on a very prominent position, emphasizing the assessment and guidance for experimental teaching, professional practice, the graduation project, and other practical aspects [1]. Engineering practice-teaching has become the core of contemporary college students' quality education.

Automation professional aims at training the wide caliber, high-quality, and compounded engineering technology professionals, who master the basic theory and the basic knowledge of the Automation field, which includes the electrical and electronic technology, control theory and control engineering, instrumentation and automation equipment, computer applications and network technology, and other professional skills. Education of Automation professional emphasizes the combination of theory and practice. The education is also pointed out on the engineering applications. Practice Teaching has played a vital role in the training process of Automation undergraduate college students [2, 3].

Practice teaching of applied engineering colleges universal exists the following outstanding issues. Firstly, the target of the practice-teaching and training is not accurate enough. Secondly, there is lack of the practice teaching resources. Thirdly, there is also lack of teachers with teaching experience in engineering practice. Fourthly, there also lack of the innovation of the content and methods of the practice-teaching. Finally, the implementation and organization of the practice of teaching lack the necessary appraisal criteria [4]. These above problems have seriously hampered the function of everyday teaching. Thus, graduates of engineering colleges are weak at the engineering practice capability and cannot meet the needs of economic and social development.

As a most significant issue affecting the quality of education, training model has always been the core of teaching reform [5]. The research-driven practice-teaching model aims to train the application-oriented and innovative talents with theory basis, strong analytical skills, good creative thinking and good ability, by the means of the students' full participation in research practice 
activities to develop students awareness of innovation and practical ability and to expand the traditional knowledge transfer model, thus to adapt to the needs of society.

\section{Goals of Reform}

\subsection{Cultivate innovative consciousness and practical ability}

The research-driven practice teaching mode trains the students with means of full participation in the research practice activities. This new mode aims to stimulate students' interest and potential in science. The students would master the professional skills necessary for the implementation process of research. Thus by the means of enhancing students' self-learning ability and knowledge-using ability, the students would be gradually cultivated to have the engineering problem analysis capabilities, engineering practical ability and sense of innovation and creative thinking.

\subsection{Expand traditional knowledge transfer models}

The latest research-driven practice teaching model is based on the traditional training model. Built on the teaching and training within the teaching program, this new model provides students with a practice platform for the application and test of the knowledge. With a view to effectively extend the professional knowledge, the new model has become an appropriate deepen and effective improvement to the traditional professional knowledge training model.

\subsection{Implement the implementation of the "student-centered, teacher-led"}

The traditional training model focused on the classroom teaching and supplemented by validation experiments. The center of learning is teacher and textbook. Students just act merely as the passive recipients of knowledge. They often lack of learning enthusiasm and initiative. Thus, the result of learning is always not ideal.

The research-driven practice teaching model focuses on cultivating students' innovative consciousness and practical ability. Students are required to self-study throughout the whole process of research and practice. Students also need to analyze independently to solve the scientific problems encountered in practice. The teacher or instructors often just plays a basic role of theoretical guidance and technical advisory. The new training model will truly implement and embody the teaching philosophy of "student-centered and teacher-led".

\section{Thinking of Reform}

(1) Advance the Student's Participation in Teacher's Research.

(2) Strengthen the Student's Participation in Various Types of Discipline Competition.

(3) Monitor the Graduate Design Topics and the Implementation Process.

(4) Expand the Construction of Research Practice Base.

\section{Contents of Reform}

\subsection{Implement University Senior Professional Tutorial}

Senior professional undergraduate tutorial system refers to the grade three or four university student pair with the professional teacher each other in accordance with the principle of two-way choice and self-combined way. The professional teachers or instructors will guide students to develop individual learning plans based on student characteristics and allow students to participate in their research activities. In this way to train the students' research and innovation ability.

Years of practice have shown that: the senior undergraduate tutorial system is an individualized cultivation mode, which helps teachers cultivate students individually. The professional teachers will provide students the conditions to participate in research projects. The students will have the opportunity to make full use of the teaching equipment, the research space and the capital resource of the school. It will provide students with the condition to participate in various academic competitions and technological innovation activities. In this way students can improve their innovative spirit and practical ability. 
Tab.1 Statistics of SRPIP Projects

\begin{tabular}{|c|c|c|c|c|c|}
\hline \multirow[b]{2}{*}{ Year } & \multicolumn{2}{|c|}{ Project Applied } & \multirow{2}{*}{$\begin{array}{l}\text { Projects } \\
\text { Accepted }\end{array}$} & \multicolumn{2}{|c|}{ Projects Finished } \\
\hline & $\begin{array}{l}\text { Project } \\
\text { number }\end{array}$ & $\begin{array}{l}\text { Students } \\
\text { involved }\end{array}$ & & $\begin{array}{l}\text { Project } \\
\text { number }\end{array}$ & $\begin{array}{l}\text { Students } \\
\text { involved }\end{array}$ \\
\hline 2005 & 33 & 160 & 20 & 8 & 97 \\
\hline 2008 & 42 & 226 & 42 & 30 & 191 \\
\hline 2009 & 58 & 340 & 58 & 38 & 268 \\
\hline 2010 & 81 & 426 & 80 & 42 & 378 \\
\hline 2011 & 78 & 418 & 69 & 38 & 275 \\
\hline 2012 & 58 & 204 & 58 & 33 & 80 \\
\hline 2013 & 61 & 143 & 61 & 30 & 108 \\
\hline 2014 & 86 & 330 & 86 & * & * \\
\hline
\end{tabular}

\subsection{Students' Full Participation in Research Work of Teachers}

In undergraduate training process, students are extensive participation in teachers' research work, for the purpose of fostering their sense of innovation and practical ability. Students can fully qualify for the professional jobs in the automation field, with their comprehensive ability to apply the knowledge to solve practical problems.

In the past five years, under the guidance of professional teachers, students have published 16 scientific papers and authorized 4 patents, wherein the three patents have industrialized and created more than 50 million yuan for the enterprise.

\subsection{Expand the University Students Specializing Discipline Contests}

Students' academic competitions should be sort out according to the automation professional features. Academic competitions carried out have shown in Tab.2. Propaganda of the academic competitions should be done well. Thus, the impact of discipline competition among the students will increase to expand the students' participation. Teachers with different knowledge background should compose contest counseling group to carry out training, guidance, and summary work after the race. Over the past five years, students have gained 51 rewards in the academic competitions above the provincial level.

Tab.2 Awards of students discipline competition in nearly 5 years

\begin{tabular}{|l|l|l|}
\hline Year & \multicolumn{1}{|c|}{ Competition } & \multicolumn{1}{|c|}{ Highest award } \\
\hline 2010 & "Challenge Cup" College Business Plan Competition & First Prize of Zhejiang Province \\
\hline 2010 & National University Students "Freescale Cup" Smart Car Contest & Second prize of East Division \\
\hline 2011 & "Challenge Cup" College Business Plan Competition & Third Prize of Zhejiang Province \\
\hline 2011 & National University Students "Freescale Cup" Smart Car Contest & Third prize of East Division \\
\hline 2011 & National Undergraduate Embedded Design Contest & National Third prize \\
\hline 2011 & Physics Innovation Contest of College Students & First Prize of Zhejiang Province \\
\hline 2011 & Mathematical Contest in Modeling & International Second prize \\
\hline 2011 & Software Design Competition & Third Prize of Zhejiang Province \\
\hline 2012 & "Challenge Cup" College Business Plan Competition & Second Prize of Zhejiang Province \\
\hline 2012 & National University Students "Freescale Cup" Smart Car Contest & Third Prize of Zhejiang Province \\
\hline 2012 & Mathematical Contest in Modeling & International First prize \\
\hline 2013 & "Challenge Cup" College Business Plan Competition & Third Prize of Zhejiang Province \\
\hline 2013 & National University Students "Freescale Cup" Smart Car Contest & Second Prize of Zhejiang Province \\
\hline 2013 & Mathematical Contest in Modeling & National Third prize \\
\hline 2014 & "Challenge Cup" College Business Plan Competition & Third Prize of Zhejiang Province \\
\hline 2014 & National University Students "Freescale Cup" Smart Car Contest & Third Prize of Zhejiang Province \\
\hline 2014 & Mathematical Contest in Modeling & Second Prize of Zhejiang Province \\
\hline 2014 & Students Physics Innovation Contest (theoretical part) & First Prize of Zhejiang Province \\
\hline 2014 & Mathematical Contest in Modeling & Second Prize of Zhejiang University \\
\hline
\end{tabular}

\subsection{Strengthen the Monitoring and Management of Practice}

The curriculum design and graduate design are the important stage to train the college students' practical ability and creative ability. The topics of the curriculum design and graduate design should combine with automation professional features. The research topic should have application value. The research topics are also the practical research urgently to be addressed. In the specific implementation process, the research work should be carried out as much as possible to reflect the actual production and scientific tasks. The curriculum design and graduate design should embody the training of practical ability and creative ability. 


\section{Supporting Policies}

\subsection{Build Practice teaching Base with School-enterprise Cooperation}

School should actively expand partnerships with the local organizations. Depending on the nature and characteristics of professional disciplines, school should select suitable enterprises and institutions to build campus practice teaching base. The enterprises and institutions should have the practice-teaching conditions and comply with the requirements of practice-teaching.

Our school has been the member of Ningbo smart appliances research strategic alliances, member of Ningbo LED lighting research strategic alliance, and member of the Electronics Industry Association of Ningbo. Our school is also the vice chairman unit of Ningbo Automation Society. Our professional has established training base with nearly 10 advanced manufacturing and modern service industries.

\subsection{Build Students' Innovation and Entrepreneurship Practice Base}

According to the requirements of innovation and entrepreneurship education, our professional actively participate in the construction of school innovation and entrepreneurship practice base. The leadership team of innovation and entrepreneurship education has been set up to develop, organize, implement, and manage the entrepreneurship training program. Assessment systems and incentives are established to improve the incentive mechanism. The special education funds are also earmarked to support the students' innovation and entrepreneurship.

\section{Conclusion}

By the means of students participating in research projects, professional discipline competitions, and innovative activities, the research-driven practice-teaching system can make up the lack of traditional teaching programs. The research-driven practice teaching model has shown be an effective way to train students' innovative consciousness and practical ability. This new model can stimulate the students' interests and potentials of scientific research. This new model can also train and shape engineering innovation and practical ability of university students. The relevant reform measures can also extend to other applied engineering specialty.

\section{Acknowledgement}

In this paper, the research was sponsored by the Professional Education Reform Research of Higher School Automation Professional Teaching Guidance Committee of Education Ministry (Project No. 2014A05) and Ningbo Educational Planning Research (Project No. 2014YGH036).

\section{References}

[1] Shi Wei. On the University Practical Teaching System [J]. Journal of Higher Education, 2013, 34 (7) 61-64.

[2] Dai Xian-zhong, Zhao Guang-zhou. Introduction to automation disciplines [M]. Beijing: Higher Education Press, 2006.

[3] Colleges Automation professional teaching steering committee of the Ministry of Education. Undergraduate automated guidance of professional norms [M]. Beijing: Higher Education Press, 2007.

[4] Liu Guo-rong. Discussion on Engineering Undergraduate Practical Teaching Reform and Innovation [J]. China Higher Education Research, 2009, 25 (5) 57-58.

[5] Wang Wei-lian. Training model: the most important issue of education quality [J]. Chinese higher education, 2009, 45(8) 24-26. 